\title{
Article/Artigo
}

\section{Mother-to-child transmission of HIV infection in Manaus, State of Amazonas, Brazil}

\author{
Transmissão materno-infantil da infecção pelo HIV em Manaus, Amazonas, Brasil
}

\author{
Claudia Marques de Oliveira Soeiro ${ }^{1}$, Angélica Espinosa Miranda ${ }^{1,2}$, Valeria Saraceni ${ }^{3}$, Noaldo Oliveira de Lucena ${ }^{1}$, \\ Sinésio Talhari ${ }^{1}$ and Luiz Carlos de Lima Ferreira ${ }^{1}$
} \begin{abstract}
Introduction: Reduction in the vertical transmission of HIV is possible when prophylactic measures are implemented. Our objective was to determine demographic characteristics of HIV-infected pregnant women and the rate of mother-to-child transmission of HIV in Manaus, Amazonas, Brazil. Methods: A descriptive study was conducted using notification, and investigating data from the Notifiable Diseases Data System in the Brazilian State of Amazonas, between 2007 and 2009. Results: During the study period, notification was received of $509 \mathrm{HIV}$-positive pregnant women. The vertical transmission was $9.9 \%$ (95\% CI: 7.2-12.6\%). The mean age of women was 27 years (SD: 5.7), and the majority (54.8\%) had not completed elementary school (eighth grade). Diagnosis of HIV seropositivity was made prior to pregnancy in 115 (22.6\%) women, during prenatal care in 302 (59.3\%), during delivery in $70(13.8 \%)$, and following delivery in $22(4.3 \%)$. Four hundred four of these women $(79.4 \%)$ had had prenatal care, with $79.4 \%$ of patients receiving antiretroviral during pregnancy and $61.9 \%$ of the newborn infants receiving prophylaxis. In the final multivariate logistic regression model, living in urban area [OR $=0.7$ (95\% CI: $0.35-0.89)]$ and having had prenatal care [OR $=0.1$ (95\% CI: 0.04-0.24)] remained as protective factors against vertical HIV transmission in this population. Conclusions: The relevance of adequate compliance with the measures already established as being effective in guaranteeing a reduction in HIV transmission within the maternal and infant population should be emphasized.
\end{abstract}

Keywords: Vertical transmission. HIV. AIDS. Pregnancy. Prophylaxis.

\begin{abstract}
RESUMO
Introdução: A redução da transmissão vertical do HIV é possível quando medidas profiláticas são implementadas. Nosso objetivo foi determinar as características demográficas de gestantes soropositivas e a taxa de transmissão vertical do HIV em Manaus, Amazonas, Brasil. Métodos: Estudo descritivo foi realizado usando dados de notificação e investigação do Sistema de Informações de Agravos de Notificações (SINAN) do Estado do Amazonas e pesquisa de informações em prontuários das gestantes na Maternidades do Município de Manaus, entre 2007 e 2009. Resultados: No período do estudo, foram notificadas 509 gestantes HIV positivas. A taxa de transmissão vertical foi de 9,9\% (95\%CI: 7.2 - 12.6\%). A idade media das pacientes era de 27 anos (SD: 5,7) e a maioria (54,8\%) não completou o ensino fundamental. O diagnóstico da infecção pelo HIV foi realizado antes da gravidez em $115(22,6 \%)$ pacientes, durante o pré-natal em 302 (59,3\%), no momento do parto em $70(13,8 \%)$ e no puerpério em 22 (4,3\%). Quatrocentos e quatro $(79,4 \%)$ gestantes tiveram acompanhamento prénatal, com $(79,4 \%)$ das pacientes recebendo drogas antirretrovirais na gestação e $61,9 \%$ dos recém-nascidos recebeu profilaxia antirretroviral. No modelo final de regressão logística multivariada, residir em área urbana [OR=0,7 (95\% CI: 0,35-0,89)] e ter realizado pré-natal $[\mathrm{OR}=0,1(95 \% \mathrm{CI}: 0,04-0,24)]$ demonstraram ser fatores protetores da transmissão vertical nesta população. Conclusões: A relevância de acompanhamento adequado e instituição de medidas já estabelecidas como efetivas em garantir a redução da transmissão vertical do HIV em gestantes e seus recém-nascidos deve ser enfatizada.
\end{abstract}

Palavras-chaves: Transmissão vertical. HIV. AIDS. Gravidez. Profilaxia.

1. Fundação Amazonas de Medicina Tropical, Universidade Estadual do Amazonas, Manaus, AM. 2. Unidade de Doenças Infecciosas, Universidade Federal do Espírito Santo, Vitória, ES. 3. Vigilância Epidemiológica, Secretaria Municipal de Saúde do Rio de Janeiro, Rio de Janeiro, RJ.

Address to: Dra. Claudia Marques de Oliveira Soeiro. Av. Constantino Nery 2.789/802, Chapada, 69 040-000 Manaus, AM, Brasil.

Phone: 5592 2127-3455

e-mail: cmosoeiro@hotmail.com

Received in 17/04/2011

Accepted in 07/06/2011

\section{INTRODUCTION}

The majority of HIV-positive women are young and of reproductive age ${ }^{1}$. The increase in the heterosexual form of transmission was an important factor in increasing the incidence of AIDS cases in women and, consequently, in increasing the number of AIDS cases in children as a result of vertical HIV transmission ${ }^{2}$.

A considerable percentage of the cases of HIV infection in the female population are diagnosed during pregnancy, reflecting the appropriateness of prenatal health-care policies requiring serological screening for $\mathrm{HIV}^{3}$. The estimated prevalence of HIV infection in pregnant women in Brazil is $0.4 \%{ }^{4}$. Between 2000 and 2009, there was a total of 47,705 HIV-positive pregnant women, with 2,095 of these cases situated in the north of the country ${ }^{3}$. Reducing vertical HIV transmission becomes viable when seropositive pregnant women are identified and treated prophylactically with antiretroviral drugs during pregnancy and delivery, and the newborn infant also is treated at birth ${ }^{5}$. Important prerequisites for the implementation of these measures include access to and the factual use of health-care services during pregnancy and delivery and in the postpartum, which must include adequately trained health-care professionals, preand post-screening counseling, available and reliable free-of-charge HIV testing, and a well-equipped and adequate laboratory in which to monitor HIV-related blood parameters ${ }^{6}$.

The Paediatric AIDS Clinical Trial Group protocol 076 (ACTG 076) has been recommended by the Brazilian Ministry of Health since 1996, and antiretroviral therapy has been made available in antenatal services and maternity clinics. Brazil adopts the policy of voluntary HIV counseling and testing for all pregnant women ${ }^{3}$. Notification of HIVpositive pregnant women cases and infants exposed to the risk of HIV transmission is compulsory (Decree no. 933 of September 4, 2000). In addition to the epidemiological aspects, the objective of implementing this measure concerns the important 
operational nature of evaluating the interventions ${ }^{7}$. Cases of vertical transmission represent $95.1 \%$ of AIDS cases in individuals younger than 14 years in Brazil. Between 1996 and June 2009, 10,739 cases of AIDS were identified in children younger than 5 years in the country, representing $2 \%$ of all cases ${ }^{3}$.

Of the various forms of HIV transmission, mother-to-child transmission is the form that has the greatest impact on control of the infection. The Ministry of Health has prioritized a program to control vertical HIV-1 transmission in an attempt to reduce transmission rates to the levels found in the United States and Europe. In fact, the vertical transmission of HIV could be considered to be the macroeconomic result of the equation between the frequency of risk factors and the investments made to avoid it ${ }^{8}$.

To increase the access of pregnant women to diagnostic tests of HIV infection, different initiatives have to be implemented to progressively decentralize HIV testing and the availability of CD4 cell counts and viral load tests9. Data on the number of infected pregnant women in the country as a whole remain sparse, and monitoring of the stages of prophylaxis to reduce vertical HIV transmission is deficient. Studies published in Brazil report a prevalence rate of vertical HIV transmission that ranges from $2.5 \%$ to $8.6 \%$ (Table 1$)^{10-20}$.

The objective of the present study was to determine sociodemographic characteristics of HIV-infected pregnant women and the rate of mother-to-child transmission of HIV in Manaus, Amazonas, Brazil.

\section{METHODS}

This study was submitted to and approved by the internal review board of the Amazonas Tropical Medicine Foundation (FMTAM). Written consent was given by the patients for their information to be stored in the hospital database and used for research.

A cross-sectional descriptive study based on data from notification records and patient charts (complementing data) for the period ranging from 2007 to 2009 was conducted with HIV-positive pregnant women living in Manaus. The data were provided by the Amazonas State Coordination for Sexually Transmitted Diseases/AIDS.

To collect epidemiological data on vertical HIV transmission, an analysis was made of the data contained in the Notifiable Diseases Database of the State of Amazonas, and a search was made of the pregnant patient charts to complement some information.

The following data were extracted from the database of HIVpositive pregnant women: age, race, education level, time at which HIV was diagnosed, whether the patient had had prenatal care, type of delivery, prophylaxis with antiretrovirals during pregnancy and delivery, prophylaxis for the newborn infant, length of time and starting date of antiretroviral use by the newborn infant, and diagnosis of HIV infection in the child. Notification data that were incomplete were updated with information from the patient's medical charts or from the birth registries of the municipal maternity hospitals.

Statistical analysis was performed using a database in Excel spreadsheet format (Microsoft ${ }^{\circledR}$ Office, Excel 2003) and the Minitab software program, version 14. First, a descriptive analysis was performed that included the frequency distribution of qualitative variables and measures of central tendency for quantitative variables. The frequency of the diagnosis in question was estimated, together with the respective $95 \%$ confidence intervals.
TABLE 1 - Studies on mother-child HIV transmission conducted in Brazil and published in the literature.

\begin{tabular}{lcccc}
\hline Author & Year & Location (city, state) & Number & \% (95\% CI) \\
\hline Tess et al. & 1998 & São Paulo, SP & 434 & $16.0(13.0-20.0)$ \\
\hline Nogueira et al. & 2001 & Rio de Janeiro, RJ & 145 & $2.8(0.1-5.4)$ \\
\hline oão et al. & 2003 & Rio de Janeiro, RJ & 297 & $3.6(1.5-5.7)$ \\
\hline Mussi-Pinhata et al. & 2003 & Ribeirão Preto, SP & 239 & $8.6(5.0-13.0)$ \\
\hline Fernandes et al. & 2005 & Campos, RJ & 44 & $6.8(1.4-18.7)$ \\
\hline Miranda et al. & 2005 & Vitória, ES & 208 & $3.1(0.8-5.5)$ \\
\hline Kakehasi & 2005 & Belo Horizonte, MG & 900 & $6.2(4.8-8.1)$ \\
\hline Dal Fabbro et al. & 2005 & Campo Grande, MS & 76 & $2.5(1.0$ to 6.0) \\
\hline Torres et al. & 2007 & Porto Alegre, RS & 389 & $2.8(1.2-4.4)$ \\
\hline Succi Menezes & 2007 & Brazil & 2,924 & $8.6(7.2-10.2)^{*}$ \\
\hline Tornatore et al. & 2010 & Rio Grande, RS & 144 & $4.9(1.4-8.4)$ \\
\hline
\end{tabular}

HIV: human immunodeficiency virus, 95\% CI: 95\% confidence interval, SP: São Paulo, RJ: Rio de Janeiro, ES: Espírito Santo, MG: Minas Gerais, MS: Mato Grosso do Sul, RS: Rio Grande do Sul.

Related to year 2000, ** Year 2001.

Bivariate analysis was then performed to check for the presence of association between the variables. Chi-square $\left(\chi^{2}\right)$ tests were used for proportion differences, and Student's t tests and variance analysis were used for testing differences between mean values. To estimate associations with vertical HIV transmission, the odds ratio was used as a measure of association, estimated with a $95 \%$ confidence interval. Multivariate analysis was performed to estimate joint effects of independent variables, through the use of logistic regression models.

\section{RESULTS}

Notification of HIV infection was received for 509 pregnant women in Manaus between 2007 and 2009. In 2007, 152 cases were notified, with an incidence rate of 4.1 cases per 1,000 pregnant women. There were 186 notified cases ( 4.9 cases per 1,000 pregnant women) in 2008 and 171 cases ( 4.5 cases per 1,000 pregnant women) in 2009 . The mean age of the women was 27 years (SD: \pm 5.7 years; range: $13-45$ years). The majority ( 478 women; $94 \%$ ) lived in urban areas, whereas 21 (4\%) lived in rural areas, and only three women resided in suburban areas.

The vertical transmission rate in this period was $9.9 \%$ (95\% CI: 7.2-12.6\%). Calculation of the vertical transmission rate was based on 48 cases of HIV-positive infants in the 487 pregnant women delivered, and in the remaining 22 cases, the pregnancy resulted in miscarriage.

The demographic data of the pregnant women in this study are described in Table 2. The majority of women were in the 20- to 29year age group $(60.6 \% ; n=308)$. Most of the women $(54.8 \%)$ had not completed elementary school (eighth grade), whereas 128 had completed high school, and only 13 women had graduated from university. In 115 (22.6\%) women, the diagnosis of HIV infection was made prior to pregnancy, whereas in 302 (59.3\%), diagnosis was made during prenatal care, in $70(13.8 \%)$ cases during delivery, and in $22(4.3 \%)$ cases following delivery. Of the 509 women, 404 (79.4\%) had attended prenatal care.

A total of 298 (58.6\%) women initiated prophylactic HIV treatment during pregnancy. In 198 (38.9\%) cases, delivery was 
TABLE 2 - Characteristics of the HIV-positive pregnant women notified between 2007 and 2009.

\begin{tabular}{|c|c|c|c|}
\hline Variables & Number & Percentage & $95 \% \mathrm{CI}^{*}$ \\
\hline \multicolumn{4}{|l|}{ Year of notification } \\
\hline 2007 & 152 & 29.9 & $25.9-33.8$ \\
\hline 2008 & 186 & 36.6 & $39.7-39.7$ \\
\hline 2009 & 171 & 33.5 & $38.5-38.5$ \\
\hline \multicolumn{4}{|l|}{ Age group } \\
\hline $13-19$ years & 34 & 6.5 & 5.4-11.9 \\
\hline $20-29$ years & 308 & 60.6 & $53.6-62.1$ \\
\hline $30-39$ years & 154 & 30.3 & $26.1-34.0$ \\
\hline$>40$ years & 13 & 2.6 & $1.9-5.1$ \\
\hline \multicolumn{4}{|l|}{ Education level } \\
\hline illiterate & 2 & 0.4 & $0.1-1.4$ \\
\hline elementary school & 279 & 54.8 & $40.4-55.9$ \\
\hline high school & 128 & 25.1 & $21.9-28.9$ \\
\hline university & 13 & 2.6 & $1.2-6.7$ \\
\hline data missing & 87 & 17.1 & $13.7-19.8$ \\
\hline \multicolumn{4}{|l|}{ Prenatal care } \\
\hline yes & 404 & 79.4 & $76.3-83.4$ \\
\hline no & 83 & 16.3 & $12.8-19.3$ \\
\hline miscarriage & 22 & 4.3 & $2.6-6.4$ \\
\hline \multicolumn{4}{|l|}{ Diagnosis of HIV } \\
\hline prior to pregnancy & 115 & 22.6 & $19.2-26.6$ \\
\hline during prenatal care & 302 & 59.3 & $54.9-63.7$ \\
\hline during delivery & 70 & 13.8 & $10.8-17.0$ \\
\hline following delivery & 22 & 4.3 & $2.8-6.6$ \\
\hline
\end{tabular}

HIV: human immunodeficiency virus, \%: percentage, 95\% CI: $95 \%$ confidence interval of frequency in the population.

vaginal, whereas in 228 (44.8\%), an elective Cesarean section was performed, and in $61(12 \%)$ cases, the women were submitted to an emergency Cesarean section. Of the liveborn infants, 317 (62.3\%) initiated treatment with antiretrovirals in the first $24 \mathrm{~h}$ after birth and $32(6.3 \%)$ after the first $24 \mathrm{~h}$, whereas 138 (27.1\%) were not submitted to prophylactic antiretroviral treatment (Table 3).

When the HIV-positive infants were compared with the HIVnegative ones in the bivariate analysis, residing in a rural area $(8.3 \%$ versus 3.7; $\mathrm{p}=0.002$ ) was found to be a risk factor for vertical transmission, whereas having a diagnosis of HIV infection prior to or during pregnancy $(41.7 \%$ versus $61.2 \%$; $=0.001)$, prophylactic
TABLE 3 - Vertical HIV transmission prophylaxis in pregnant women notified between 2007 and 2009.

\begin{tabular}{|c|c|c|c|}
\hline Variables & Number & Percentage & 95\% CI* \\
\hline \multicolumn{4}{|c|}{ Use of antiretroviral during pregnancy } \\
\hline yes & 298 & 58.6 & $49.1-68.2$ \\
\hline no & 135 & 26.5 & 19.7-31.1 \\
\hline data missing & 54 & 10.6 & $4.0-12.2$ \\
\hline not applicable * $^{*}$ & 22 & 4.3 & $2.5-6.1$ \\
\hline \multicolumn{4}{|l|}{ type of delivery } \\
\hline vaginal & 198 & 38.9 & $23.6-48.0$ \\
\hline elective cesarean & 228 & 44.8 & $38.1-59.2$ \\
\hline emergency cesarean & 61 & 12.0 & 7.1-19.5 \\
\hline not applicable ${ }^{*}$ & 22 & 4.3 & 2.5-6.1 \\
\hline \multicolumn{4}{|c|}{ Use of antiretroviral during delivery } \\
\hline yes & 278 & 54.6 & $45.8-64.5$ \\
\hline no & 155 & 30.5 & $26.8-44.5$ \\
\hline data missing & 54 & 10.6 & $6.2-13.6$ \\
\hline not applicable* & 22 & 4.3 & $2.5-6.1$ \\
\hline \multicolumn{4}{|l|}{ outcome of pregnancy } \\
\hline live born infant & 481 & 94.5 & $87.4-99.8$ \\
\hline stillborn infant & 6 & 1.2 & $0.5-3.4$ \\
\hline miscarriage & 22 & 4.3 & $2.5-6.1$ \\
\hline \multicolumn{4}{|c|}{ Initiation of antiretroviral therapy in the newborn } \\
\hline in the first $24 \mathrm{~h}$ & 317 & 62.3 & $52.7-72.4$ \\
\hline more than $24 \mathrm{~h}$ after delivery & 32 & 6.3 & 3.5-7.9 \\
\hline not applicable ${ }^{*}$ & 22 & 4.3 & $2.5-6.1$ \\
\hline not used & 138 & 27.1 & $17.9-43.1$ \\
\hline \multicolumn{4}{|l|}{ HIV-positive newborn infant } \\
\hline yes & 48 & 9.9 & $7.2-12.6$ \\
\hline no & 439 & 90.1 & $87.4-92.7$ \\
\hline
\end{tabular}

HIV: human immunodeficiency virus, n: number, \%: percentage, 95\% CI: 95\% confidence interval of frequency in the population.

${ }^{*}$ Not applicable: patients excluded due to miscarriage, ${ }^{* *} 95 \% \mathrm{CI}: 95 \%$ confidence interval of frequency in the population.

antiretroviral therapy for the infant $(31.3 \%$ versus $54.7 \%$; $\mathrm{p}=0.001)$ and delivery by elective Cesarean section (27.1\% versus $46.9 \%$; $\mathrm{p}=0.010)$ constituted protective factors.

In the final multivariate logistic regression model, living in an urban area $[\mathrm{OR}=0.7$ (95\% CI: 0.35-0.89) $]$ and having had prenatal care $[\mathrm{OR}=0.1$ (95\% CI: 0.04-0.24) $]$ remained as protective factors against vertical HIV transmission in this population (Table 4).

TABLE 4 - Multivariate analysis of factors associated with HIV vertical transmission among pregnant women notified in Manaus between 2007 and 2009.

\begin{tabular}{lccc}
\hline Factors & Adjusted Odds ratio & 95\% CI & p value \\
\hline Living in an urban area (yes versus no) & 0.71 & $0.35-0.89$ & 0.018 \\
\hline Attending prenatal care (yes versus no) & 0.13 & $0.04-0.24$ & 0.009 \\
\hline HIV diagnostic during pregnancy or delivery versus HIV diagnostic before pregnancy & 1.48 & $0.79-2.73$ & 0.215 \\
\hline HIV prophylaxis during pregnancy (yes versus no) & 0.81 & $0.63-1.10$ & 0.119 \\
\hline HIV prophylaxis during delivery (yes versus no) & 0.75 & $0.36-1.54$ & 0.434 \\
\hline HIV prophylaxis in the first 6h after delivery (yes versus no) & 0.50 & $0.11-2.24$ & 0.366 \\
\hline Delivery (vaginal versus cesarean section) & 1.22 & $0.76-1.97$ & 0.415 \\
\hline Pregnancy outcome (stillborn/miscarriage versus alive) & 1.48 & $0.87-2.51$ & 0.149 \\
\hline
\end{tabular}

HIV: human immunodeficiency virus, 95\% CI: 95\% confidence interval. 


\section{DISCUSSION}

The rate of vertical HIV transmission in Manaus between 2007 and 2009 was $9.4 \%$. In a multicenter study conducted in Brazil, Menezes Succi reported a rate of vertical transmission of $7.1 \%$ (95\% CI: 5.8\%-8.6\%) in 2001 for Brazil as a whole, ranging from $4.9 \%$ in the midwest to $17.6 \%$ in the north ${ }^{19}$. The prevalence in the present study, although still high, was lower than the value calculated for the northern region in the multicenter study. ${ }^{19}$ This may be explained by the fact that Manaus is not representative of the entire region because it is the largest city in terms of urban area and probably has better health-care facilities compared with the other municipalities in the region. Furthermore, the health conditions in the region improved after the previously conducted 2001 study.

The rate of vertical transmission in Manaus identified in the present study is in agreement with that found in other studies carried out in Brazil, which range from $2.5 \%$ to $8.6 \%^{10-20}$. These rates found in Brazil are higher than those reported in studies published in Europe, where prophylactic measures are implemented early in pregnancy, resulting in mother-to-child transmission rates of around $1 \%{ }^{21-25}$.

The mean age of the HIV-positive pregnant women in the present study was 27 years. In Brazil, $55 \%$ of notified cases of pregnant women with AIDS fall within the 20- to 29-year age group 3 . The majority of seropositive pregnant women in Manaus (54.8\%) had, at most, some elementary education. Approximately $50 \%$ of the HIV-positive women in Brazil have between 1 and 7 years of schooling ${ }^{3}$. The poor education level of these women hampers their access to information on HIV, placing the woman and her family at an even greater risk of HIV transmission ${ }^{18}$.

Delayed diagnosis of HIV infection may have been the reason in the present study for the fact that less than $70 \%$ of the seropositive women used antiretrovirals during pregnancy to prevent vertical transmission. The fact that $79.4 \%$ of the patients stated that they had undergone prenatal care is relevant. The Sentinel Childbirth Study conducted in 2004 reported that only $62.5 \%$ of the women giving birth had undergone HIV testing during pregnancy and were aware of the result of their test prior to being admitted to hospital for delivery ${ }^{4}$. Other studies conducted in Brazil also have reported the difficulty of access to prenatal care and problems in blood sampling and in receiving the results of HIV screening tests during pregnancy and delivery ${ }^{14,26,27}$. These data show that prophylactic actions related to vertical HIV transmission remain deficient with respect to prevention and care. This situation is aggravated when it is taken into consideration that the act of providing a blood sample for testing does not guarantee that the woman will receive the results of her test, which would permit awareness of her HIV serological status and consequently enable preventive measures to be implemented.

The situation also differs from country to country. In 2008, $45 \%$ of HIV-positive pregnant women in Sub-Saharan Africa were receiving antiretrovirals ${ }^{1}$. In Botswana, $37 \%$ had begun highly active antiretroviral therapy during pregnancy, whereas $42 \%$ were using only zidovudine prophylactically, and $21 \%$ received no medication at all during pregnancy ${ }^{28}$. In Asia, only $25 \%$ of pregnant women had access to antiretrovirals ${ }^{1}$. In Western Europe and in the United States, vertical transmission is considered to be under control ${ }^{29}$.
In the present study, $54.6 \%$ of the women received zidovudine in the maternity hospital, whereas $30.5 \%$ were not treated prophylactically at the time of delivery in Manaus, and the remaining women miscarried prior to initiating prophylaxis. In a study carried out in the Brazilian State of Maranhão, 78.5\% of seropositive pregnant women failed to receive adequate prophylaxis to prevent vertical transmission, and $55 \%$ of the babies were delivered vaginally ${ }^{30}$. This high rate of vaginal delivery, which also was found in the present study, has been reported by other authors. ${ }^{31,32}$ Of the deliveries carried out in HIV-positive pregnant women in Manaus during the study period, $38.9 \%$ were vaginal, whereas $56.8 \%$ of the women were submitted to Cesarean section. Nevertheless, Cesarean sections were elective in only $44.8 \%$ of these patients, whereas in the remaining $12 \%$, they occurred as the result of an obstetric emergency in which labor had already begun and amniotic membrane rupture may already have occurred, a situation that may incur a risk of transmission at the moment of delivery.

In Manaus, $62.3 \%$ of the infants were treated with antiretrovirals within $24 \mathrm{~h}$ of birth, whereas almost $30 \%$ were not submitted to prophylaxis. The data found in the present study are disquieting and reveal a severe shortcoming in maternal and child health care, particularly with respect to the prevention of vertical HIV transmission during pregnancy. In other states in Brazil, antiretroviral use was much higher ${ }^{15}{ }^{18}$. The low use of antiretrovirals as prophylaxis during pregnancy in Manaus is probably the result of the delayed diagnosis of HIV infection in pregnant women. These findings raise other questions such as the following: Was there a delay in initiating prenatal care? When the tests were performed, were the results provided in time? Was prenatal care being provided by a multidisciplinary team in a complete and satisfactory manner as appropriate for the care of an HIV-positive pregnant woman?

The present study is unable to provide answers to these questions in view of the limited data available in the databases, patient charts, and registries of the maternity hospitals; however, it is important to highlight the role of prenatal care in adopting strategies for reducing vertical HIV transmission.

Although antiretroviral therapy is offered universally in Brazil, the proportion of HIV-positive pregnant women who do not have access to the prophylactic measures recommended by the National Department of Sexually Transmitted Diseases/AIDS and Viral Hepatitis, and who ultimately fail to be tested for HIV, remains high, either as a function of the women's social condition or due to inadequacies in the health-care system. Late detection of HIV infection during prenatal care represents an opportunity to intervene in the case of the HIV-infected patient that is lost, thus limiting the possibilities of reducing the number of pediatric cases caused by vertical transmission ${ }^{4}$.

Adequate prenatal care implemented early in pregnancy and access to HIV testing are measures that are crucial to achieving a reduction in vertical transmission rates. Based on the findings of the present study, the relevance of adequately complying with measures that have proven effective in reducing HIV transmission in the maternal and pediatric populations should be emphasized. These actions should be carried out by a trained multidisciplinary team. The social and economical impact of these measures on the country is potentially significant. 


\section{ACKNOWLEDGMENTS}

The authors thank the Coordenação Estadual de AIDS do Amazonas for the technical support and donation of the AIDS databases and the Public Maternity Hospitals of Manaus for the permission to review medical records.

\section{CONFLICT OF INTEREST}

The authors declare that there is no conflict of interest.

\section{REFERENCES}

1. Joint United Nations Programme on HIV/AIDS (UNAIDS). The 2008 Report on the Global AIDS Epidemic. Geneva: UNAIDS; 2009.

2. Brito AM, Sousa JL, Luna CF, Dourado I. Trends in maternal-infant transmission of AIDS after antiretroviral therapy in Brazil. Rev Saude Publica 2006; 40:18-22.

3. Ministério da Saúde. Secretaria de Vigilância em Saúde. Boletim Epidemiológico AIDS. Ano VI nº 1. Brasília: Ministério da Saúde; 2006.

4. Souza-Júnior PRB, Szwarcwald CL, Barbosa Júnior A, Carvalho MF, Castilho EA HIV infection during pregnancy: the Sentinel Surveillance Project, Brazil, 2002. Rev Saude Publica 2004; 38:764-772.

5. Connor EM, Sperling RS, Gelber R, Kiselev P, Scott G, O'Sullivan MJ, et al Reduction of maternal-infant transmission of human immunodeficiency virus type 1 with zidovudine treatment. Pediatric AIDS Clinical Trials Group Protocol 076 Study Group. N Engl J Med 1994; 331:1173-1180.

6. Nishimoto TMI, Eluf Neto J, Rozman MA. Mother-to-child transmission of human immunodeficiency virus (HIV-I): evaluation of control measures in the city of Santos. Rev Assoc Med Bras 2005; 51:54-60.

7. Cavalcante MS, Ramos Jr AN, Pontes LRSK. Linkage of health information systems: a strategy to optimize the surveillance of pregnant women infected by HIV. Epidemiol Serv Saúde 2005; 14:127-133.

8. Duarte G, Quintana SM, El Beitune P. Risk factors for vertical transmission of the human immunodeficiency virus type 1. Rev Bras Ginecol Obstet 2005; 27:698-705

9. Lemos LMD, Gurgel RQ, Dal Fabbro AL. Prevalence of infection within unified health care system maternities. Rev Bras Ginecol Obstet 2005; 27:32-36.

10. Tess BH, Rodrigues LC, Newell ML, Dunn DT, Lago TD. Infant feeding and risk of mother-to-child transmission of HIV-1 in São Paulo State, Brazil. São Paulo Collaborative Study for Vertical Transmission of HIV-1. J Acquir Immune Defic Syndr Hum Retrovirol 1998; 19:189-194.

11. Nogueira SA, Abreu T, Oliveira R, Araújo L, Costa T, Andrade M, et al. Successful prevention of HIV transmission from mother to infant in Brazil using a multidisciplinary team approach. Braz J Infect Dis 2001; 5:78-86.

12. João EC, Cruz ML, Menezes JA, Matos HJ, Calvet GA, d'Ippolito MM, et al. Vertical transmission of HIV in Rio de Janeiro, Brazil. AIDS 2003; 17:1853-1855.

13. Mussi-Pinhata MM, Kato CM, Duarte G, Paschoini MC, Bettiol H, Quintana SM. Factors associated with vertical HIV transmission during two different time periods: the impact of zidovudine use on clinical practice at a Brazilian reference center. Int J STD AIDS 2003; 14:818-825

14. Fernandes RC, Araújo LC, Medina-Acosta E. Prevention of vertical HIV transmission in Campos dos Goytacazes, Rio de Janeiro, Brazil. Cad Saude Publica $2005 ; 21: 1153-1159$

15. Miranda AE, Soares RA, Prado BC, Monteiro RB, Figueiredo NC. Mother to child transmission of HIV in Vitória, Brazil: factors associated with lack of HIV prevention. AIDS Care 2005; 17:721-728.

16. Kakehasi FM, Pinto JA, Romanelli RM, Carneiro M, Cardoso CS, Tavares MDT et al. Determinants and trends in perinatal human immunodeficiency virus type 1 (HIV-1) transmission in the metropolitan area of Belo Horizonte, Brazil: 1998 - 2005. Mem Inst Oswaldo Cruz 2008; 103:351-357.

17. Dal Fabbro MM, Cunha RV, Paniago AM, Lindenberg AS, Freitas GM, Nogueira SA. Prospective study on the prevention of vertical transmission of HIV in Campo Grande, Mato Grosso do Sul, Brazil, from 1996 to 2001. Braz J Infect Dis 2005; 9:20-27.

18. Torres SR, Luz AMH. HIV + pregnant woman and exposed children epidemiological study on compulsory notification. Rev Gauch Enferm 2007; 28:505-511.

19. Menezes Succi RC. Mother-to-child transmission of HIV in Brazil during the years 2000 and 2001: results of a multi-centric study. Cad Saude Publica 2007; 23 (suppl 3); 3:379-389.

20. Tornatore M, Gonçalves CV, Mendoza-Sassi RA, Silveira JM, D’ávila NE Maas CG, al. HIV-1 vertical transmission in Rio Grande, Southern Brazil. Int J STD AIDS 2010; 21:351-355.

21. Fernández-Ibieta M, Ramos Amador JT, Guillén Martín S, González-Tomé MI Navarro Gómez M, Gonzalez-Nicolas I, et al. Why are HIV-infected infants still being born in Spain? An Pediatr (Barc) 2007; 67:109-115.

22. Townsend CL, Cortina-Borja M, Peckham CS, Ruiter A, Lyall H, Tookey PA. Low rates of mother-to-child transmission of HIV following effective pregnancy interventions in the United Kingdom and Ireland, 2000-2006. AIDS 2008; 22:973-981

23. Goetghebuer T, Haelterman E, Marvillet I, Barlow P, Hainaut M, Salameh A et al. Vertical transmission of HIV in Belgium: a 1986-2002 retrospective analysis. Eur J Pediatr 2009; 168:79-85.

24. European Collaborative Study, Boer K, England K, Godfried MH, Thorne C. Mode of delivery in HIV-infected pregnant women and prevention of mother-to-child transmission: changing practices in Western Europe. HIV Med 2010; 11:368-378.

25. Pádua E, Almeida C, Nunes B, Cortes Martins H, Castela J, Neves C, et al Assessment of mother-to-child HIV-1 and HIV-2 transmission: an AIDS reference laboratory collaborative study. HIV Med 2009; 10:182-190.

26. Maturana AP, Rizzo CV, Vasquez DF, Cavalheiro N, Holzer S, Morais VS Evaluation of delivery assistance in HIV infected pregnant women. Arq Med ABC 2007; 32:11-16.

27. Morimura MCR, Mendes MDC, Souza AI, Alencar LCA. HIV testing prevalence during antenatal care in women admitted for delivery at the Instituto Materno Infantil Professor Fernando Figueira, IMIP. Rev Bras Saude Mater Infant 2006; 6:S69-S76.

28. Chen JY, Ogwu AC, Svab P, Lockman S, Moffat HJ, Gaolathe T, et al Antiretroviral Treatment Initiation Among HIV-Infected Pregnant Women with Low CD4(+) Cell Counts in Gaborone, Botswana.J Acquir Immune Defic Syndr 2010; 54:102-106.

29. Newell ML, Huang S, Fiore S, Thorne C, Mandelbrot L, Sullivan JL, et al. Characteristics and management of HIV-1-infected pregnant women enrolled in a randomised trial: differences between Europe and the USA. BMC Infect Dis 2007; 7:60.

30. Maluf e Silva MJ, Mendes WS, Gama MEA, Chein MBC, Veras DS. Clinical and laboratory profile of children living with vertically transmitted HIV/AIDS in a city in northeastern Brazil. Rev Soc Bras Med Trop 2010; 43:32-35.

31. Yoshimoto CE, Diniz EMA, Vaz FAC. Clinical and laboratory evolution of children born to HIV positive mothers. Rev Assoc Med Bras 2005; 51:100-105.

32. Ioannidis JP, Abrams EJ, Ammann A, Bulterys M, Goedert JJ, Gray L, et al Perinatal transmission of human immunodeficiency virus type 1 by pregnant women with RNA virus loads $<1000$ copies/ml. J Infect Dis 2001; 183:539-545. 